\title{
ASSIGNMENT OF THE HUMAN CYTOCHROME P-450 NIFEDIPINE OXIDASE GENE (CYP3A4) TO CHROMOSOME 7 AT BAND q22.1 BY FLUORESCENCE IN SITU HYBRIDIZATION
}

\author{
Kiyoshi Inoue, ${ }^{1}$ Johji Inazawa, ${ }^{2}$ Hitoshi Nakagawa, ${ }^{3}$ \\ Tsutomu Shimada, ${ }^{1}$ Hiroshi Yamazaki, ${ }^{1}$ F. Peter Guengerich, ${ }^{4}$ \\ and Tatsuo $\mathrm{ABE}^{2}$ \\ ${ }^{1}$ Osaka Prefectural Institute of Public Health, \\ Nakamichi, Higashinari-ku, Osaka 537, Japan \\ ${ }^{2}$ Department of Hygiene and ${ }^{3}$ Department of Medicine, Kyoto Prefectural \\ University of Medicine, Kamigyo-ku, Kyoto 602, Japan \\ ${ }^{4}$ Department of Biochemistry and Center in Molecular Toxicology, \\ Vanderbilt University School of Medicine, Nashville, TN37232, U.S.A.
}

\begin{abstract}
Summary We have used a full length cDNA clone $(2.2 \mathrm{~kb})$ for the human cytochrome P-450 nifedipine oxidase (CYP3A4) enzyme as a probe to determine its chromosome localization by fluorescence in situ hybridization. CYP3A4 was mapped on R-banded human prometaphase chromosomes, and the precise localization of CYP3A4 on chromosome 7 was further confirmed by a delineation of G-banded pattern on the same prometaphase chromosomes through a combination of UV-filter. We assigned CYP3A4 to chromosome 7 at q22.1.
\end{abstract}

Key Words fluorescence in situ hybridization, CYP3A4, chromosomal mapping, chromosome 7

\section{INTRODUCTION}

Cytochrome P-450 (P-450) is an important enzyme system involved in the oxidative metabolism of drugs and carcinogens as well as endogenous compounds. Nebert et al. (1991) have recently reported that the P-450 gene superfamily comprises about 27 gene families with more than 150 genes. The human cytochrome P-450 nifedipine oxidase gene (CYP3A4) encodes a human liver P-450 responsible for the oxidation of many drugs and carcinogens including the calcium-channel blocker nifedipine and related dihydropyridine derivatives (Brian et al., 1990). Using somatic cell hybrids, the gene for a P-450 that encodes the enzyme nifedipine oxidase (CYP3) was localized to human chromosome 7 (Riddell et al., 1987; Gonzalez et al., 1988). Spurr et al. (1989) assigned CYP3 to 7q22-qter with the use of

Received February 5, 1992; Accepted March 11, 1992. 
a panel of human-rodent somatic cell hybrids, and Brooks et al. (1988) mapped the gene to the band 7q21.3-q22.1 using multilocus linkage analysis in Centre d'Etude Polymorphisme Humain (CEPH) families. However, no regional mapping of CYP3A4 has been proposed.

In recent years, in situ hybridization techniques using biotinylated probes have been used to develop so called fluorescence in situ hybridization (FISH) for precise localization of human genes on chromosomes. FISH techniques have simplified and shortened the handling process while increasing the sensitivity for detection and resolution, as compared to original in situ hybridization methods using isotopically labeled probes. However, only a few results on the simultaneous localization of short single-copy genes on banded human chromosomes by FISH have been reported (Viegas-Péquignot et al., 1989; Hori et al., 1990).

In this paper, we report the precise and direct localization of CYP3A4 by means of combining FISH on the human R-banded chromosomes, synchronized by treatment with excess-thymidine followed by 5 -bromodeoxyuridine (BrdU) incorporation during the late $\mathrm{S}$-phase. This system has made it possible to obtain excellent $\mathrm{G}$ banded chromosomes by changing the filter combination to Nikon filter UV-2A.

\section{MATERIALS AND METHODS}

Preparation of high resolution R-banded chromosomes. High resolution Rbanded chromosomes were obtained after human lymphocyte cultures, synchronized by excess-thymidine followed by BrdU incorporation during the late S-phase (ViegasPéquignot and Dutrillaux, 1978; Takahashi et al., 1990). Chromosome preparations were made according to standard procedures, including treatment with a hypotonic solution and fixation with methanol/acetic acid $(3: 1, \mathrm{vol} / \mathrm{vol})$. The fluorescence staining method of detecting R-banded chromosomes was carried out according to protocols described previously (Tsuji and Kato, 1981).

$D N A$ probes and labeling. A NF-25 cDNA clone $(2.2 \mathrm{~kb}$ insert) related to the human cytochrome P-450 nifedipine oxidase gene (Beaune et al., 1986) was used. The cDNA clone was labeled by nick translation using biotin-16-dUTP according to the directions of the supplier (Boehringer, Mannheim). After the reaction was terminated by heating at $65^{\circ} \mathrm{C}$ for $10 \mathrm{~min}$, the biotinylated probe was purified by an ethanol precipitation method using $4 \mathrm{M}$ ammonium acetate (Wako) and sonicated salmon DNA containing Escherichia coli tRNA $(10 \mathrm{mg} / \mathrm{ml})$. The probe was used at a level of $500 \mathrm{ng}$ per slide.

In situ hybridization. In situ hybridization and rinsing was carried out according to the protocol described by Takahashi et al. $(1989,1990)$ with slight modification (Inazawa et al., 1991). The hybridization mixture consisted of $0.5 \mu \mathrm{g}$ biotinlabeled cDNA, $50 \%$ formamide, $2 \times \mathrm{SSC}, 10 \%$ bovine serum albumin (BSA), and $20 \%$ dextran sulfate (final concentration). After the slides were incubated overnight at $37^{\circ} \mathrm{C}$ in a humid chamber, they were washed sequentially with $50 \%$ formamide- $2 \times \mathrm{SSC}$ at $37^{\circ} \mathrm{C}$ and then $2 \times \mathrm{SSC}$ and $1 \times \mathrm{SSC}$ at room temperature for 15 
min each. The slides were then immersed in $4 \times$ SSC.

Cytochemical detection. The cytochemical detection was done by the protocol described by Pinkel et al. (1986) with some modifications. The slides were removed from the $4 \times$ SSC solution and incubated with a blocking solution $(4 \times$ SSC containing $4 \%$ Block Ace ${ }^{\mathrm{TM}}$ powder) for $10 \mathrm{~min}$ at $42^{\circ} \mathrm{C}$. The slides were then incubated with $4 \times$ SSC containing $5 \mu$ g avidin-FITC (Boehringer) per $\mathrm{ml}$ and $1 \%$ Block Ace ${ }^{\text {TM }}$ powder (Dainippon, Osaka) at $37^{\circ} \mathrm{C}$ for $45 \mathrm{~min}$ in a humid chamber. They were then washed by shaking sequentially in $4 \times \mathrm{SSC}, 4 \times \mathrm{SSC}$ containing $0.05 \%$ Triton $X-100$, and $4 \times$ SSC for $10 \mathrm{~min}$ each at room temperature. After washing, as described above, the intensity of biotin-linked fluorescence was amplified by adding a layer of biotinylated anti-avidin D (Vector, Burlingame, CA) (1 $\mu \mathrm{g} / \mathrm{ml}$ in $4 \times \mathrm{SSC}$ containing $1 \%$ Block $\mathrm{Ace}^{\mathrm{TM}}$ powder), followed by washing as above and then incubation with another layer of avidin-FITC in $4 \times \mathrm{SSC}$ with $1 \%$ Block Ace ${ }^{\mathrm{TM}}$ powder at $37^{\circ} \mathrm{C}$. After washing by shaking, as above, the slides were counterstained with a solution containing $1 \mu \mathrm{g}$ propidium iodide (PI, Sigma) per ml and mounted with a fluorescence anti-fade solution containing $p$-phenylenediamine (Johnson et al., 1981). Slides were observed and photographed using a fluorescence microscope (Nikon). The fluorescein and PI were excited at 450-490 nm (Nikon filter combination B-2A). The DNA-specific dye PI was used to stain the chromosomes red, and the greenish-yellow fluorescein signal of the hybridized probe was simultaneously observed. The use of another filter combination, B-2E (exciter 450-490 nm, barrier 520-560 nm), allowed observation of more contrasted yellow signals on green chromosomes. Moreover, excitation in the ultraviolet (Nikon filter combination UV-2A) allowed the observation of the G-banded chromosomes. Fujichrome 400 D color slide film (Fuji) was used for microphotographs.

\section{RESULTS AND DISCUSSION}

To determine the chromosomal localization of CYP3A4, we applied FISH techniques allowing simultaneous identification of fluorescent signals on highresolution $\mathrm{R}$-banding chromosomes. The technique also allows identification of the G-band and location of the signals on the same preparation by changing filters (Fig. 1, A and B). Filter combination UV-2A allowed an optimal observation of G-banded chromosomes with excitation near the wavelength of $365 \mathrm{~nm}$. This mapping was performed directly with a biotinylated $2.2 \mathrm{~kb}$ long fragment inserted in bacteriophage $\lambda$ gt11. Because of the small size of $2.2 \mathrm{~kb}$ probe it is difficult to detect the hybridization signals in the original system (Viegas-Péquignot et al., 1989). We adopted the procedure of labeling with avidin-FITC, followed by biotinylated anti-avidin D, and then a second labeling with avidin-FITC. The fluorescence intensity was increased significantly by these treatments.

The detailed analysis was performed with 100 metaphase cells, 34 of which showed fluorescent signals on band 7q22. The distribution pattern of the signals on $7 \mathrm{q} 22$ was as follows: twin spots on both homologs of chromosome $7(8.8 \%)$,

Vol. 37, No. 2, 1992 

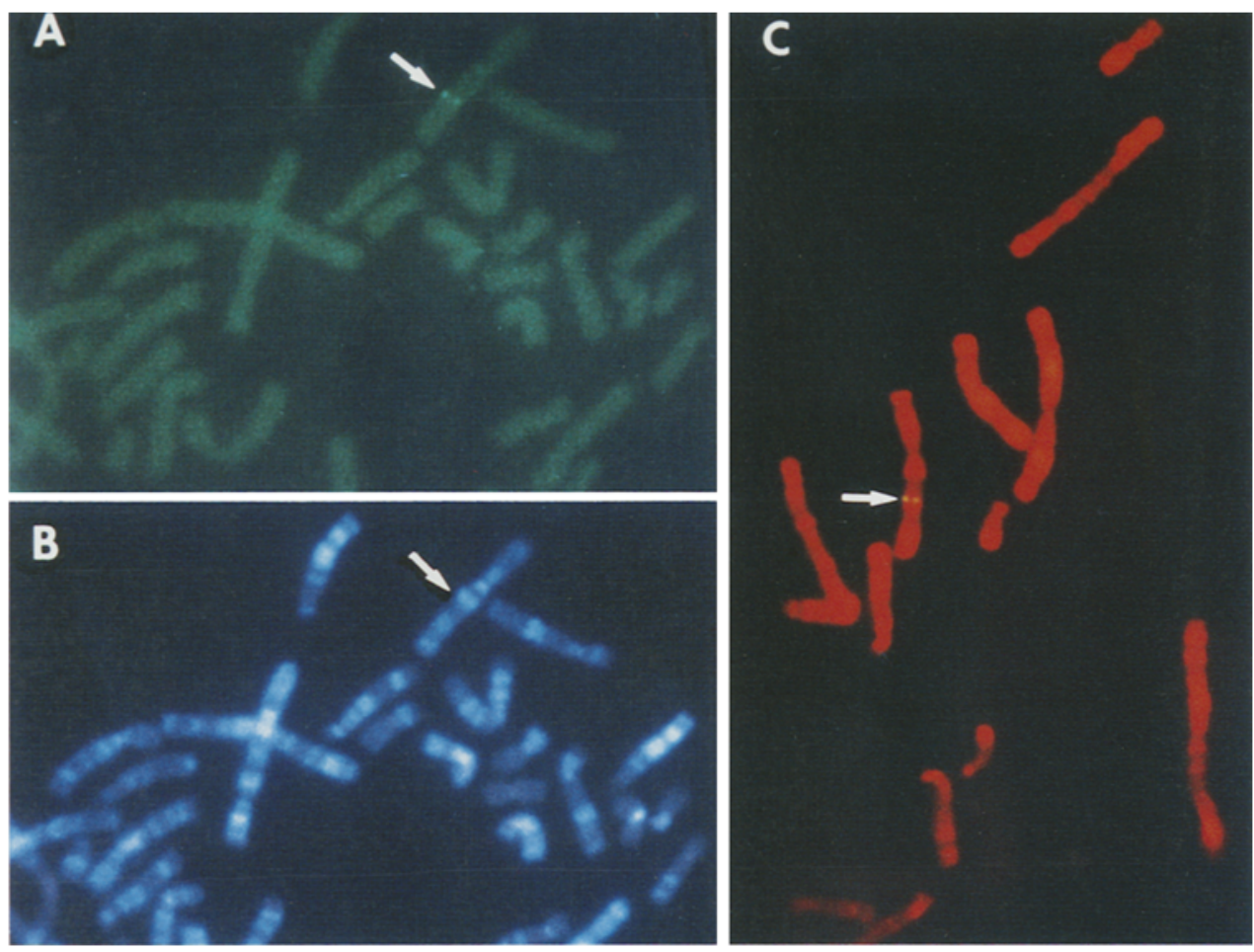

Fig. 1. Chromosomal localization of CYP3A4 gene by fluorescence in situ hybridization. (A) Fluorescent signals for CYP3A4 gene were detected on the long arm of chromosome 7 (filter combination B-2E Nikon). (B) The G-banding pattern on the same metaphase was delineated through different filter combination (UV-2A Nikon), showing the signals at 7q22.1. (C) Simultaneous visualization of R-bands and hybridization signal (filter combination B-2A Nikon). Arrow indicates hybridization signals on $7 \mathrm{q} 22.1$.

twin spots on one homolog and single spot on the other $(11.8 \%)$, twin spots on only one homolog $(70.6 \%)$, and a single spot on only one homolog $(8.8 \%)$. No such twin fluorescent signals were detected on other chromosomes. CYP3A4 was assigned on typical R-banded chromosomes, and the precise localization of CYP$3 \mathrm{~A} 4$ on chromosome 7 was further confirmed by a delineation of G-banded pattern on the same metaphase chromosomes through a combination of UV-filter (Nikon UV-2A). Of 34 metaphase cells that showed fluorescent signals in the $7 \mathrm{q} 22$ region, $91.2 \%$ were located on $7 \mathrm{q} 22.1,2.9 \%$ on the interface between $7 \mathrm{q} 21.3$ and $7 \mathrm{q} 22.1$, $5.9 \%$ on $7 \mathrm{q} 22.2$. Thus, CYP3A4 was assigned to the $7 \mathrm{q} 22.1$ band of the human karyotype (Fig. 1C).

This mapping system has made it possible to directly identify the localization of signals on the R-banded chromosomes and to delineate the G-banded pattern 
on the same metaphase chromosome through a different filter combination (UV-2A, wavelength $365 \mathrm{~nm}$ ).

Acknowledgment This work was supported in part by Grant-in Aid from the Special Coordination Funds for Promoting Science and Technology, Science and Technology Agency, and from the Ministry of Education, Science and Culture, Japan.

\section{REFERENCES}

Beaune PH, Umbenhauer DR, Bork RW, Lloyd RS, Guengerich FP (1986): Isolation and sequence determination of a cDNA clone related to human cytochrome P-450 nifedipine oxidase. Proc Natl Acad Sci USA 83: 8064-8068

Brian WR, Sari M-A, Iwasaki M, Shimada T, Kaminsky LS, Guengerich FP (1990): Catalytic activities of human liver cytochrome P-450 IIIA4 expressed in Saccharomyces cerevisiae. Biochemistry 29: 11280-11292

Brooks BA, McBride OW, Dolphin CT, Farrall M, Scambler PJ, Gonzalez FJ, Idle JR (1988): The gene CYP3 encoding P450PCN1 (nifedipine oxidase) is tightly linked to the gene COL1A2 encoding collagen type I alpha on 7q21-q22.1. Am J Hum Genet 43: 280-284

Gonzalez FJ, Schmid BJ, Umeno M, McBride OW, Hardwick JP, Meyer UA, Gelboin HV, Idle JR (1988): Human P450PCN1: sequence, chromosome localizatiom, and direct evidence through cDNA expression that P450PCN1 is nifedipine oxidase. DNA 7: 79-86

Hori T, Takahashi E, Ayusawa D, Takeishi K, Kaneda S, Seno T (1990): Regional assignment of the human thymidylate synthase (TS) gene to chromosome band $18 \mathrm{p} 11.32$ by nonisotopic in situ hybridization. Hum Genet 85: 576-580

Inazawa J, Fukunaga R, Seto Y, Nakagawa H, Misawa S, Abe T, Nagata S (1991): Assignment of the human granulocyte colony-stimulating factor receptor gene (CSF3R) to chromosome 1 at region $\mathrm{p} 35-\mathrm{p} 34.3$. Genomics 10: 1075-1078

Johnson GD, Nogueira Araujo GMC (1981): A simple method of reducing the fading of immunofluorescence during microscopy. J Immunol Methods 43: 349-350

Nebert DW, Nelson DR, Coon MJ, Estabrook RW, Feyereisen R, Fujii-Kuriyama Y, Gonzalez FJ, Guengerich FP, Gunsalus IC, Johnson EF, Loper JC, Sato R, Waterman MR, Waxman DJ (1991): The P450 superfamily: update on new sequences, gene mapping, and recommended nomenclature. DNA Cell Biol 10: 1-14

Pinkel D, Straume T, Gray JW (1986): Cytogenetic analysis using quantitative, high-sensitivity, fluorescence hybridization. Proc Natl Acad Sci USA 83: 2934-2938

Riddell DC, Wang H, Umbenhauer DR, Beaune PH, Guengerich FP, Hamerton JL (1987): Regional assignment for the genes encoding human P450IIIA3 (CYP3) and P450IIC9 (CYP2). Cytogenet Cell Genet 46: 682

Spurr NK, Gough AC, Stevenson K, Wolf CR (1989): The human cytochrome P450 CYP3 locus: assignment to chromosome 7q22-qter. Hum Genet 81: 171-174

Takahashi E, Hori T, Lawrence JB, McNeil J, Singer RH, O'Connell P, Leppert M, White R. (1989): Human type II collagen gene (COL2A1) assigned to chromosome 12q31.1-q13.2 by in situ hybridization with biotinylated DNA probe. Jpn J Human Genet 34: 307-311

Takahashi E, Hori T, O'Connell P, Leppert M, White R (1990): R-banding and nonisotopic in situ hybridization: precise localization of the human type II collagen gene (COL2A1). Hum Genet 86: 14-16

Tsuji H, Kato H (1981): Three-way differential staining sister chromatids in M3 chromosomes; evidence for spontaneous sister chromatid exchanges in vitro. Exp Cell Res 134: 433-444

Viegas-Péquignot E, Dutrillaux B (1978): Une methode simple pour obtenir des prophases et des prometaphases. Ann Genet (Paris) 21: 122-124 
Viegas-Péquignot E, Dutrillaux B, Magdelenat $H$, Coppey-Moisan M (1989): Mapping of singlecopy DNA sequences on human chromosomes by in situ hybridization with biotinylated probes: enhancement of detection sensitivity by intensified-fluorescence digital-imaging microscopy. Proc Natl Acad Sci USA 86: 582-586 